УДК 616.31- 089.444

DOI 10.11603/2411-1597.2019.2.10195

\title{
СТАН, ПРОБЛЕМИ І ПЕРСПЕКТИВИ ВПРОВАДЖЕННЯ ПАЛІАТИВНОЇ ТА ХОСПІСНОЇ ДОПОМОГИ В УКРАЇНІ
}

\author{
Г. В. Савка \\ ДВНЗ «Тернопільський національний медичний університет \\ імені І. Я. Горбачевського МОз Украӥни»
}

У статті висвітлено та проаналізовано стан, проблеми і перспективи впровадження паліативної та хоспісної допомоги в Україні.

\section{STATE, PROBLEMS AND PERSPECTIVES OF IMPLEMENTATION OF PALIATIVE AND HOSPICE CARE IN UKRAINE}

\author{
H. V. Savka
}

\section{Horbachevsky Ternopil National Medical University}

The article analyzes the status, problems and prospects of palliative and hospice care in Ukraine.

Вступ. Однією з найактуальніших проблем сьогодення залишаються питання старіння населення більшості країн світу та невпинне, мало контрольоване зростання ряду тяжких та невиліковних хвороб. Для України теж $\epsilon$ реальністю процес старіння населення, зростання таких хвороб, як онкологічні захворювання, туберкульоз, ВІЛ/СНІД, цукровий діабет, гепатит C, гематоонкологічні проблеми, особливо у дітей, стабільно високий рівень інсультів, інфарктів та їх тяжких ускладнень, промисловий та побутовий травматизм тощо.

Згідно з даними різноманітних досліджень національних та міжнародних експертів, в Україні щороку близько 500 тис. осіб потребують паліативної та хоспісної допомоги та, додатково, психологічна і соціальна допомога потрібна їхнім сім'ям та близьким. Загалом це може становити від 1 до 2 млн людей, які разом будуть задіяні в подоланні труднощів боротьби з невиліковною хворобою, фізичним та духовним болем.

Лікування та догляд за цими пацієнтами, величезні кошти на лікування та соціальні компенсаторні витрати лягають тягарем як на плечі сім'ї, так і нашої держави. Тому актуальне нелегке для вирішення якнайшвидшого та масштабного впровадження в соціальне та медичне сьогодення країни питання організації та розвитку паліативно-хоспісної допомоги.

(c) Г. В. Савка, 2019
Відповідно до сучасних міжнародних підходів і концепцій та згідно з закликами ВООЗ, паліативна медицина повинна бути невід'ємною, інтегрованою складовою медичного обслуговування та соціальної опіки і входити в структуру національних систем охорони здоров'я.

Метою написання цієї статті $\epsilon$ спроба висвітлення ретроспективи та сучасного стану паліативно-хоспісної допомоги в Україні.

Основна частина. Перед Україною постали важливі та нелегкі питання впровадження в медико-соціальну роботу паліативно-хоспісної допомоги вже давно, практично з перших днів здобуття незалежності. Досі в Україні діє застаріла пострадянська модель опіки над людьми похилого та старечого віку з невиліковними хворобами. Для старших людей, які з віком вже мали цілий «букет» хронічних хвороб, функціонували спеціальні інтернати та так звані «будинки престарілих», у яких вони доживали життя та помирали під наглядом команди соціальних та медичних працівників.

Хворими на туберкульоз опікувалися в протитуберкульозних диспансерах місцевого, обласного та республіканського рівнів. Також була своя специфіка лікування та нагляду за хронічно та тяжкохворими пацієнтами в онкологічних, ендокринологічних, психоневрологічних та інших диспансерах різного рівня підпорядкування. Найтяжчі пацієнти помирали або в 
спеціально відведених палатах спеціалізованих відділень, або найчастіше, вдома, на руках у рідних та близьких, в стражданнях та болю.

В Україні, на відміну від більшості держав Європи та світу, практично не існувало закладів із надання паліативно-хоспісної допомоги. Перші з них почали створюватися в 90-х роках XX століття за ініціативою закордонних благодійних організацій та деяких церков [4].

Про створення паліативної допомоги в Україні говорять давно, але, крім цих палких промов, виступів на авторитетних зібраннях та в матеріалах конгресів, з'іздів та журнальних статей нічого не було зроблено. Одними з прихильників найшвидшого впровадження паліативно-хоспісної допомоги в Україні були такі знані та авторитетні лікарі та вчені нашої держави, як В. М. Князевич (міністр охорони України 2007-2010 рр.), Ю. В. Вороненко (ректор НМАПО імені П. Л. Шупика), Ю. І. Губський, А. В. Царенко, О. О. Вольф, Н. Г. Гойда [3].

В. М. Князевич був першим із міністрів охорони здоров'я України, який вказав на розвиток паліативної допомоги в Україні, як на пріоритет у своїй діяльності на цій посаді. В Україні був створений проект «Концепція Державної програми розвитку паліативної та хоспісної допомоги в Україні на 2010-2014 рр.». За авторством В. М. Князевича, А. В. Царенко, І. В. Яковенко, О. П. Брацюнь, на Першому Національному Конгресі з паліативної допомоги, що проводили в м. Ірпіні, 26-27 вересня 2012 р., був викладений проект «Національна стратегія створення та розвитку системи паліативної допомоги в Україні». А вже в 2013 р., ті ж самі автори внесли на розгляд керівництва держави та громадського загалу документ під назвою «Стан, проблеми і перспективи впровадження Національної стратегії розвитку системи паліативної допомоги в Україні до 2022 р.» [2].

За останні роки в Україні відбулися значні зміни в організації та функціонуванні паліативно-хоспісної допомоги. Створені та функціонують близько 40 закладів, що надають паліативну допомогу та діють на різних засадах - державних, комунальних, благодійних. Це такі заклади, як Волинська обласна лікарня «Хоспіс», м. Луцьк; Херсонська обласна лікарня «Хоспіс»; Івано-Франківська обласна лікарня «Хоспіс»; «Хоспіс Святої Олени», м. Коростень; Харківський обласний центр паліативної медицини «Хоспіс»; Львівська міська лікарня «Хоспіс»; Благодійний заклад Хоспіс «Архангела Михаїла», м. Запоріжжя; відділення паліативної допомоги (на базі міської лікарні № 4), м. Львів; відділення паліативної допомоги (на базі обласної психоневрологічної лікарні), м. Чернігів; відділення паліативної допомоги (на базі обласного туберкульозного диспансеру), с. Надбугське-2, Миколаївська область; відділення паліативної допомоги (на базі центральної районної лікарні), м. Мукачево, Закарпатська область; паліативне відділення на базі Шпиталю імені Митрополита Шептицького, м. Львів; відділення паліативної допомоги (при Київському міському онкоцентрі); відділення паліативної допомоги (при Київській міській клінічній лікарні № 2); відділення паліативної допомоги (при Київській міській клінічній лікарні № 10); Харківський міський «Хоспіс»; відділення паліативної допомоги (на базі районної Виноградівської лікарні), Закарпатська область; відділення паліативного і медсестринського догляду (на базі міської лікарні № 10), м. Маріуполь, Донецька область; Дубенський хоспіс (на базі Дубенського міжрайонного онкодиспансеру); геронто-психіатричне відділення, що надає паліативну допомогу, Полтавської обласної клінічної психіатричної лікарні ім. О. Ф. Мальцева та ряд інших.

В Україні лише незначній частці пацієнтів надається необхідна стаціонарна й амбулаторна паліативна допомога. В результаті - сотні тисяч пацієнтів у термінальній стадії онкологічних та багатьох хронічних невиліковних захворювань, які потребують паліативної та хоспісної допомоги, помирають вдома наодинці, страждаючи від болю, депресії, інших симптомів захворювань, через відсутність професійного догляду, соціальної та психологічної підтримки [5].

Першу позицію за поширеністю серед причин смерті та потреби у паліативній допомозі серед дорослого населення України посідають хвороби системи кровообігу, далі йдуть злоякісні новоутворення, хронічні обструктивні захворювання легень, цироз печінки, туберкульоз, ВІЛ/СНІД, цукровий діабет, захворювання нирок, хвороба Паркінсона, хвороба Альцгеймера та ревматоїдний артрит (рис. 1).

Практично в кожній області України планується відкриття хоспісів чи центрів із надання паліативнохоспісної допомоги невиліковно хворим громадянам України.

За попередніми експертними оцінками, в Україні повинно бути не менше 3 тис. стаціонарних ліжок для паліативної та хоспісної допомоги. За підрахунками експертів ВООЗ, потреба в паліативній допомозі становить на 100 тис. населення в середньому 7 ліжок у 


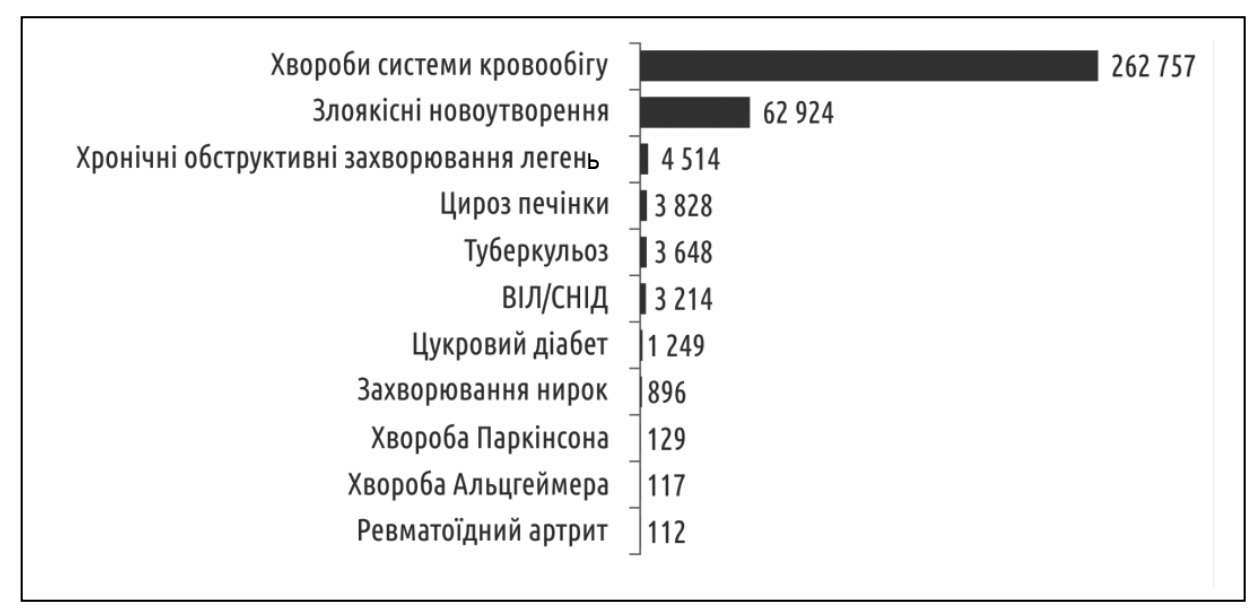

Рис. 1. Потреба у паліативній допомозі - дорослі, вся Україна.

стаціонарах і 10 хворих, які потребують паліативної допомоги вдома.

Виходячи з цього, в Україні повинно бути не менше 3,7 тис. паліативних ліжок. Крім цього, близько 85 тис. хворих щоденно потребують паліативної допомоги вдома [1].

У межах презентації щорічного дослідження «Індекс здоров'я. Україна 2018» дослідницька група презентувала результати опитування відносно догляду за особою або особами, які не можуть самостійно про себе піклуватися через довготривалу або невиліковну хворобу, тяжку травму чи немічність. Нагадаємо, «Індекс здоров'я Україна» - це щорічне дослідження з метою визначення фактичного рівня задоволеності громадян України медичною допомогою.

Догляд за людьми, які потребують довготривалого догляду:

- 6 \% опитаних здійснювали/організовували догляд;

- 30 год/тиждень витрачали на догляд;

- у 32 \% випадків хворий потребував сильнодіючих знеболювальних засобів;

- кожен третій хворий, який потребував цих засобів, - їх не отримав.

Однак діючі в Україні паліативні та хоспісні відділення лікувально-профілактичних закладів вкрай обмежені в ресурсах і не мають можливості забезпечити хворих навіть найнеобхіднішим: медичним обладнанням, протипролежневими матрацами та іншими засобами медичного призначення [6].

Через брак коштів, на жаль, матеріально-технічна база багатьох діючих хоспісів та відділень паліативної допомоги ще не відповідає стандартам, а умови перебування хворих у цих закладах $є$ незадовільними, що можна розглядати як порушення прав пацієнтів. Однак на державному рівні це питання намагаються врегулювати [7]. До прикладу, на базі Київської медичної академії післядипломної освіти відкрита та плідно працює кафедра паліативної медицини, яка підготувала сотні фахівців у цьому напрямку. Окремо хотілося 6 вказати на позитивні зміни в підготовці студентів вищих навчальних закладів I-IV рівнів акредитації на додипломному етапі навчання. Так, з ініціативи Т. І. Чернишенко (директор центру), І. Я. Губенко (директор), І. В. Радзієвська, Л. П. Бразалій (Черкаський базовий медичний коледж), М. Б. Шегедин (Львівський медичний коледж імені Андрея Крупинського) були створені та запроваджені в практичну діяльність навчальні програми, внесені для вивчення такі дисципліни, як «Геронтологія та геріатрія», «Медсестринство в геронтології, геріатрії та паліативній медицині».

Для магістрів медсестринства існує програма вивчення дисципліни «Паліативна медицина», для слухачів курсів післядипломної освіти впроваджена і працює програма «Медсестринство в паліативній і хоспісній допомозі», створені підручники для навчання майбутніх лікарів, фельдшерів та медичних сестер на додипломному етапі навчання. При ВНКЗ «Дубненський медичний коледж» - директор Н. О. Венгрин, у кінці 2010, на початку 2011 р., було створено та функціонує відділення паліативної допомоги (хоспіс). Догляд за його підопічними здійснюють викладачі цього навчального закладу. Крім того, проводять виїзні курси з паліативної медицини та хоспісної допомоги для практичних лікарів та медичних сестер різних відділень в лПз мОЗ України. Проводять наукові конференції та конгреси різного рівня як міжнародні, так і національні, всеукраїнські. Остання науково-практична конференція з міжнародною участю «Паліативна допомога в Україні: морально-етичні, психологічні та духовні аспекти» 
відбулася 14-15 червня 2016 р. у м. Харкові. 32015 р. почали видавати Міжнародний журнал «Реабілітація та паліативна медицина» (головний редактор - доктор медичних наук В. М. Князевич), інформаційний бюлетень «Паліативна допомога», постійно проводять ґрунтовні медико-соціальні аналітичні дослідження, за результатами яких здійснюють огляди ситуації на різних державних та науково-практичних рівнях.

В Україні, після багаторічних досліджень, вже почали захист дисертацій з теми створення та впровадження, адаптованих до українських реалій, моделей надання паліативно-хоспісної допомоги - Ж. М. Золотарьова (Івано-Франківськ, 2015 р.) «Обґрунтування моделі удосконалення підготовки та підвищення кваліфікації медичного персоналу для надання паліативної допомоги». Активно та широко в Україні застосовують рекомендації Європейського регіонального бюро ВООЗ «Паліативна допомога» (2005), «Вдосконалення паліативної допомоги людям старечого віку» (2005), ЄАПД. «Біла книга стандартів з паліативної допомоги: рекомендації Європейської асоціації паліативної допомоги» (2011), ЄАПД. Празька хартія «Отримання паліативної допомоги - право людини» (2013) [8].

Що стосується питання юридично-правового супроводу офіційного оформлення та діяльності в Україні процесу паліативно-хоспісної допомоги, то і тут, відбулися позитивні зміни. За останні роки в Україні було прийнято низку нових законів із питань паліативно-хоспісної допомоги [2, 7]:

- Про організацію паліативної допомоги в Україні: наказ МОЗ України від 21.01.2013 р. № 41.

- Перелік медичних показань для надання паліативної допомоги, затверджений наказом МОЗ України від 21.01.2013 р. № 41.

- Про затвердження Порядку взаємодії суб'єктів при наданні соціальної послуги паліативного догляду вдома невиліковно хворим: наказ Міністерства соціальної політики України та Міністерства охорони здоров'я України від 23.05.2014 р. № 317/353, зареєстрований у Міністерстві юстиції України від 13.06.2014 р. № 625/25402.

- Про затвердження Примірного положення про лікарню «Хоспіс» (відділення, палату паліативного лікування) для хворих на туберкульоз: наказ МОз України від 11.06.2010 р. № 483.
- Про затвердження та впровадження медико-технологічних документів зі стандартизації паліативної медичної допомоги при хронічному больовому синдромі: наказ МОЗ України від 25.04.2012 р. № 311.

- Порядок взаємодії суб'єктів при наданні соціальної послуги паліативного догляду вдома невиліковно хворим: спільний наказ Мінсоцполітики та МОЗ України від 23.05.2014 р. № 317/353.

В останні роки починає розвиватися чітка, багаторівнева структура надання паліативно-хоспісної допомоги в Україні. Вона передбачає створення нових, ремонти, переоснащення та забезпечення кваліфікованими кадрами тих закладів, що мають в цьому потребу. Також створюють мережу дитячих хоспісів та хоспісних закладів [5].

У деяких областях України вже сформовані та працюють виїзні відділення та бригади з надання паліативно-хоспісної допомоги. Поступово обговорюють та впроваджують в практику ідею створення домашніх хоспісів. Ця форма надання паліативно-хоспісної допомоги дуже позитивно зарекомендувала себе за кордоном, у т. ч. і в сусідній з Україною Польщі та в Німеччині (Баварії), Нідерландах, Словаччині. Багаторічний досвід цих та ряду інших країн використовує наша держава в моделюванні багаторівневої мультидисциплінарної паліативно-хоспісної допомоги. В Україні неможливо уявити процес становлення та розвитку паліативно-хоспісної допомоги без волонтерських об'єднань та духовної допомоги церков різних християнських конфесій. Так, в Україні функціонує Всеукраїнська громадська організація «Українська ліга сприяння розвитку паліативної та хоспісної допомоги». 3 моменту її заснування активно підтримували та долучалися і покійний митрополит УПЦ МП Володимир, і митрополит УПЦ КП Філарет, керівник УГКЦ Блаженніший Л. Гузар, а також представники інших християнських конфесій України [4].

Висновки. Надання паліативно-хоспісної допомоги в Україні потребує подальшого розвитку як на рівні створення нових та модернізації вже створених відділень, так і в питанні підготовки достатньої кількості фахівців - медичних сестер та лікарів, соціальних працівників. 


\section{СПИСОК ЛІТЕРАТУРИ}

1. Медико-соціальні проблеми становлення паліативної допомоги в Україні / Н. М. Величко, О. О. Вольф, Т. І. Вялих, В. В. Чайковська // Соціальна політика щодо невиліковно хворих : матеріали Всеукр. наук.-практ. конф., 15-16 берез. 2012 р. - К. : Університет «Україна», 2012. - C. 37-43.

2. Порядок надання паліативної допомоги, затверджений наказом МОЗ України від 21.01.2013 р. № 41 // Офіційний вісник України. - 2013. - № 13. - С. 78-79.

3. Князевич В. М. Стан, проблеми і перспективи впровадження Національної стратегії розвитку системи паліативної допомоги в Україні до 2022 р. / В. М. Князевич, А. В. Царенко, І. В. Яковенко // Паліативна допомога в Україні: складові та шляхи розвитку : матеріали науковопрактичної конференції (м. Харків, 18-19 вер. 2014 р.) ; за ред. В. М. Князевича, Ю. І. Губського, А. В. Царенка. - К., 2014. - 92 c.

4. Царенко А. В. Міжнародні підходи щодо розвитку паліативної та хоспісної допомоги / А. В. Царенко // Актуальні питання надання паліативної та хоспісної допомоги в Україні : матеріали Першої наук.-практ. конф. ; за ред. Ю. В. Вороненка, Ю. І. Губського. - К. : Університет «Україна», 2012. - С. 168-176.

5. Про організацію паліативної допомоги в Україні [Електронний ресурс] : наказ МОЗ України від 21.01.2013 р. № 41. - Режим доступу : http://zakon2.rada. gov.ua/laws/show/z0229-13.

6. Про державну реєстрацію (перереєстрацію) лікарських засобів та внесення змін до реєстраційних матеріалів [Електронний ресурс] : наказ МОЗ України від 01.02.2013 р. № 77. - Режим доступу : http://old.moz. gov.ua/ua/print/dn_20130201_0077.html.

7. Про затвердження Порядку придбання, перевезення, зберігання, відпуску, використання та знищення наркотичних засобів, психотропних речовин і прекурсорів у закладах охорони здоров'я [Електронний ресурс] : Постанова Кабінету Міністрів України від 13.05.2013 р. № 333. - Режим доступу : http://zakon4.rada.gov.ua/laws/ show/333-2013-\%D0\%BF.

8. Біла книга стандартів з паліативної допомоги : рекомендації Європейської Асоціації паліативної допомоги, 2001.

Отримано 21.03.19 